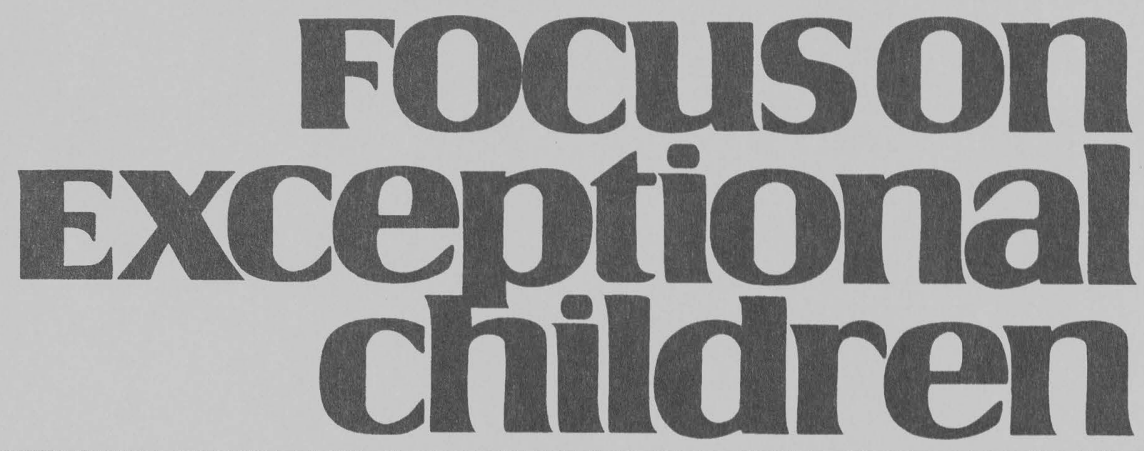

\title{
High-Access Instruction: Practical Strategies to Increase Active Learning in Diverse Classrooms
}

\author{
Kevin Feldman and Lou Denti
}

Determining how to enhance teaching and motivate students to learn continues to present a challenge for educators. The challenge today is, perhaps, greater than ever, as more diverse students with complex academic and emotional needs look to teachers for social support and academic assistance. Adding to the problem is the fact that creating opportunities for students with learning challenges to access the district's or school's core curriculum of study requires a significant shift in teaching attitude and focus. Research-validated instructional methods have made a substantial difference for students with diverse learning needs, but all too often, creating the time for teachers to learn these methods is not of high priority for the district or school. Further, the organization of schools is sometimes structured in a way that prevents powerful teaching, innovative organizational arrangements, and new curricular approaches. As Peter Senge, organizational expert, stated, "Schools may fail to incorporate research-validated practices for students with learning disabilities because schools themselves suffer from learning disabilities" (cited in Knight, 1998, p. 1). To truly meet the academic and social needs of a diverse population of students, organizations will need to re-create themselves to meet this diversity head-on, or they will be left sideswiped by an anachronistic system geared for a student who no longer exists (Katz \& Denti, 1996).

The ensuing discourse challenges schools to redesign themselves based on the given that every classroom contains a diverse group of students with large variances in prior knowledge, skills, motivation, and ability in English. More specifically, it responds to the demands of classroom diversity by providing empirically valid and practical learning strategies that teachers can implement without extensive training. Further, it suggests that traditional approaches (e.g., undifferentiated curriculum, "sage on the stage" teaching, removing children who do not fit) only serve to widen the gaps between successful and struggling students. Challenging the notion that schools are for those students who "do school well," this article offers teachers a view of powerful instruction that empowers all students. The focus of the article is the following question: How can teachers more effectively respond to classroom diversity and help all students improve or "get smarter"?

Kevin Feldman is the director of reading and early intervention for the Sonoma County Office of Education, and he is an adjunct professor of special education at Sonoma State University. He also serves as a leadership team consultant to the California Reading and Literature Project. Lou Denti is a Lawton Love Distinguished Professor of Special Education in the Center for Collaborative Education and Professional Studies at California State University at Monterey Bay. This article was adapted from New Ways of Looking at Learning Disabilities: Connections to Classroom Practice published by Love Publishing Company. 


\section{WHY CHANGE THE WAY WE TEACH?}

The data over the past 25 years suggest that lower level classes and special classes for students with learning difficulties often produce an opposite effect from the original intent, which was to provide intensive individualized instruction to improve or ameliorate the identified problem (Ensminger, 1991; Stainback \& Stainback, 1984; Steinberg, 1991; Wang, Reynolds, \& Walberg, 1986). By their very nature, these classes dilute or supplant the core curriculum, often rescuing or enabling students via a tutorial or remedial approach (Deshler \& Schumaker, 1986). The result has been a less capable learner unequipped to deal with the exigencies of the general education classroom or the real world (Zigmond \& Thorton, 1985). Just as distressing, many students with learning problems give up, give in, act out, become indifferent, or drop out-an indictment, so to speak, of a system unable to adapt to meet students' needs.

To offset the negative aspects of separate schooling for students with learning disabilities, educators in the past decade have touted inclusion as educationally sound and "right." Though inclusionary efforts have been meritorious,

\section{Focuson
Exceptional
children}

ISSN 0015-511X

FOCUS ON EXCEPTIONAL CHILDREN (USPS 203-360) is published monthly except June, July, and August as a service to teachers, special educators, curriculum specialists, administrators, and those concerned with the special education of exceptional children. This publication is annotated and indexed by the ERIC Clearinghouse on Handicapped and Gifted Children for publication in the monthly Current Index to Journals in Education (CIJE) and the quarterly index, Exceptional Children Education Resources (ECER). The full text of Focus on Exceptional Children is also available in the electronic versions of the Education Index. It is also available in microfilm from Xerox University Microfilms, Ann Arbor, MI. Subscription rates: individual, \$36 per year; institutions, $\$ 48$ per year. Copyright (c) 2004, Love Publishing Company. All rights reserved. Reproduction in whole or part without written permission is prohibited. Printed in the United States of America. Periodical postage is paid at Denver, Colorado. POSTMASTER: Send address changes to:

$$
\begin{gathered}
\text { Love Publishing Company } \\
\text { Executive and Editorial Office } \\
\text { P.O. Box } 22353 \\
\text { Denver, Colorado } 80222 \\
\text { Telephone (303) 221-7333 }
\end{gathered}
$$

\section{EDITORIAL BOARD}

Edwin Ellis

University of Alabama
Tim Lewis

University of Missouri

Chriss-Walther Thomas

University of Kansas

Susan T. Warhover Editor
Stanley F. Love Publisher they have not garnered the necessary support and resources to gain unilateral acceptance at most schools. Further, teachers lack the training and time to develop an appropriate opportunity structure for students with learning disabilities in general education classrooms (Denti, 1994). Whether a school is using pullout programs or inclusive programs, the need to provide more intensive focused instruction to students labeled learning disabled and other low-achieving students is critical.

On that note, we now turn to what we have called highaccess instruction (HAI). High-access instruction is a method of teaching that uses instructional strategies designed to ensure that all teachers and students are actively engaged in the learning process. The remainder of this article defines HAI, contrasts high- and low-access strategies, and describes how high-access instruction can be implemented by classroom teachers.

\section{THE CHALLENGE OF INCORPORATING HIGH-ACCESS INSTRUCTION IN SCHOOL CLASSROOMS}

As a society, we can legislate and mandate opportunitythink, for example, of desegregation and inclusion-but legislation does not ensure access. That is, we can place students with learning disabilities in general education classrooms and tell ourselves that they have expanded opportunities, but the actual research data (Vaughn \& Schumm, 1995; Vaughn, Schumm, Jallad, Slusher, \& Saumell, 1996; Zigmond \& Baker, 1995) document that students with learning disabilities do not have the same access to classroom activities as their peers.

According to a growing body of research (McIntosh, Vaughn, Schumm, Haager, \& Lee, 1993; Schumm, Vaughn, Gordon, \& Rothlein, 1994), general education teachers have provided opportunities for students with learning disabilities to participate in the same activities as nonlabeled peers, but few adaptations or enhancements have been made. Differentiation of the curriculum to support students with learning challenges has rarely been observed. Moreover, Vaughn and Schumm (1995) found that students with learning disabilities participated minimally in general education classes. For these students, they observed low levels of participating in class, asking for help, answering and asking questions, engaging with peers, participating in teacher-directed activities, and following through with homework. Further, they found that general education classroom teachers expected less of students with learning disabilities. The teachers asked the students with learning disabilities fewer questions, interacted with them less in discussion, provided them with less feedback, and monitored their group work less. These findings occurred across grade levels and were exaggerated at middle and high 
school levels. The authors concluded that there appeared to be a tacit assumption between general education teachers and students with learning disabilities that went something like this: "You don't bother me, and I won't bother you!"

Any rethinking of the learning disabilities paradigm must go beyond concepts of inclusion and mainstreaming to address learning activities in the classroom that empower and engage all learners. Significant changes are required on the part of general and specialist teachers to ensure that high-access instruction becomes the norm in schools serving diverse learners.

What we propose fundamentally challenges the very nature of instruction in classrooms. High-access instruction sees all students as potential assets rather than problems. It also asks teachers to analyze their teaching and look for areas where instruction may be "breaking down," rather than blame their students for not understanding the content. By shifting the paradigm of instruction to variables the teacher controls, high-access instruction lays the groundwork for more interaction between teachers, students, ancillary staff, and parent volunteers.

\section{HIGH-ACCESS INSTRUCTION: WHAT IS IT?}

High-access instruction is a way of teaching that uses empirically sound and valid learning strategies to (a) actively engage all learners in a classroom, (b) maximize student participation, and (c) ensure that diverse learners focus their attention on critical concepts and big ideas (Kameenui \& Carnine, 1998). High-access instruction combines many strategies that have their roots in cooperative learning, direct instruction, and critical thinking. These approaches have a sound research base and can be effectively implemented in almost any type of classroom at any grade level.

High-access instruction frames teaching from the perspective of "everyone does everything" in the classroom. The teacher's role shifts from disseminator of information to choreographer of learning. The lesson/unit design incorporates dynamic interaction with students. The teacher's job is to get all students actively engaged and participating. Simply put, HAI encourages students to think, speak, write, touch, build, listen, practice - to actively learn. It frames the issue of student diversity in terms of variables that teachers can powerfully respond to, rather than in terms of problems to be eliminated via administrative fiat. As Keogh (1990) indicated nearly a decade ago, major changes are needed in the delivery of services to problem learners, and these services need to be the responsibility of general and special educators. She further pointed out that teachers are the central players in bringing about change in practice and that our most pressing challenge is to determine how to improve the quality of instruction at the classroom level.
High-access instruction is an answer to Keogh's cry for change at the classroom level. It provides teachers with a means for employing concrete learning strategies at every stage of a lesson or unit, from brainstorming and predicting before new content is taught to structured review after a lesson. Many examples of high-access learning strategies are provided in this article to help teachers gain an understanding of how to employ these powerful teaching methods in their classrooms. In addition, the article points out the limited viability of low-access instruction.

\section{WHAT DOES NOT WORK: A BRIEF LOOK AT COMMON LOW-ACCESS TEACHING PRACTICES}

Before we examine the details of high-access instructional strategies, we present a brief look at some common lowaccess teaching practices to provide a point of comparison. The majority of these low-access teaching routines are not harmful or "bad" in and of themselves; however, they are likely to be ineffective in today's diverse classrooms because they assume homogeneity among very diverse students. Low-access practices tend to treat all students as if they have the same skill levels, motivation, fluency in English, and prior knowledge about various content area subjects. As such, they limit the ability of many students to interact with the teacher, think critically, or construct new meaning.

A significant first step to crafting schools and classrooms that truly work for all kinds of learners is to ensure that teachers' instructional "tool kits" are well stocked with validated strategies that engage every student in the learning process so that teachers may better resist using low-access strategies.

\section{Hand Raising}

The most powerful thing a teacher can do to ensure real access to powerful learning experiences may be deceptively simple: Stop the age-old practice of hand raising as the primary way to structure discussion and other forms of discourse in the classroom. It has been repeatedly documented (e.g., Cohen, 1994; Goodlad, 1984) that dramatic inequity exists in classroom verbal interactions as early as kindergarten and that these troubling social structures persist through graduate school. Some students can't get enough of the teacher's attention, continually having their hands in the air, responding to every question, blurting out answers, and so forth, while others sit quietly, either bored or daydreaming, fearful of looking inept, or otherwise disengaged from the instructional conversation. It comes as no surprise that the correlation between classroom interaction and student achievement is significant and that the "die gets cast" at an early age. All teachers know it is not the low-achieving 
student, the second-language learner, the student with disabilities, or the less confident student who raises his or her hand to contribute. Thus, a logical first step for a teacher desiring to change this inequitable classroom sociology is to stop engaging in the practice of asking questions and waiting for students to raise their hands with a response.

\section{Allowing Students to Blurt Out Answers}

Blurting out answers as soon as the teacher poses a question is the primary-grade "cousin" to hand raising. Eager students often want to show their enthusiasm and intelligence by shouting out the answer before much of the class has even figured out the question! While teachers may admonish students who blurt out answers, subtle cues often communicate that this behavior is acceptable and indicative of a quick mind. However, the student who shouts out answers is unwittingly depriving his or her classmates of the valuable thinking time that they need to cognitively process the question and construct a viable response.

\section{Round-Robin Reading}

One of the most common forms of passage reading in schools is known as round-robin reading, where students take turns reading aloud while the rest of the class or group follow along. Though this is practice fraught with difficulties, just one of which being that only one student is actively engaged in the reading activity, it persists as a salient teaching method in most classrooms. Teachers who dismiss this method have reported that many students are so busy counting the lines until their turn to read that they pay little attention to the student who is reading aloud. In addition, less able students are often anxiety ridden awaiting their turn and then humiliated by demonstrating to the whole class their lack of skill in oral reading.

\section{Unstructured Group Work}

"Get into groups and discuss the meaning of the homework," exhorts a well-intended middle school teacher. The problem with this type of instruction is that, lacking a clear objective, the groups will simply replicate the inequities of the larger classroom. One student will likely dominate and take over the conversation while others will be uninvolved or off task. Group work can be a powerful alternative to whole class instruction or independent seat work (Slavin, 1984), but only if the groups are carefully structured to ensure positive interdependence and individual accountability for learning the information.

\section{Undifferentiated Curriculum-"One Size Fits All"}

Assigning everyone the same homework assignment, the same stories for individual reading, the same format for projects, and so on, ensures frustration for students who do not have the required prior knowledge and skills to derive benefit from the activity. Yet teachers often find themselves confronting the reality of using an elementary reading anthology ordered by their district's central office for use with all students at their grade, regardless of the fact that one half or more of their students cannot independently read the books. Vygotsky (1978) and others have documented that instruction must be provided at a student's instructional level, or zone of proximal development. This cannot be done with a "straitjacket" curriculum that assumes homogeneity in heterogeneous classrooms.

\section{Undifferentiated Teaching- "Sage on the Stage"}

The corollary to undifferentiated curriculum is undifferentiated instruction. The teacher who views teaching as essentially communicating information via oral recitation to a group of students limits opportunities for learning. Goodlad's (1984) groundbreaking study documented that "sage on the stage" teaching was the most established and universal form of classroom instruction and was especially commonplace at the secondary level. Very little has changed since that study. Yet oral recitation ignores the fact that classrooms with many diverse learners require teachers to do more than simply cover the material. They need to scaffold new information via the effective use of various instructional strategies designed to teach students how to learn (Simmons \& Kameenui, 1996).

In sum, many of the most common general instructional practices are not effective because they assume homogeneity among students. It is not enough, however, to simply stop engaging in nonproductive instructional routines such as hand raising; teachers need clear alternatives that increase access to critical skills and information for the wide variety of students in today's classrooms. Classroom teachers of the 21 st century need to be equipped with a "tool kit" of instructional tactics and strategies that have been documented to work with diverse learners, including students labeled learning disabled. High-access instructional strategies are one set of tools that research suggests can significantly assist teachers in meeting the challenge of creating classrooms that truly work for all students.

\section{HIGH-ACCESS INSTRUCTIONAL STRATEGIES}

The goal of high-access instructional strategies is to ensure that all students have meaningful access to the content of lessons through active-engagement learning activities. The instructional tactics assume that diverse students will have varying amounts of prior knowledge about any given topic as well as varying proficiency in English and a wide range of basic skills in reading, writing, and mathematics. 
Additionally, high-access instructional strategies strive to provide a safe, nonthreatening environment within which students can practice developing skills and explore new information. The following sections briefly describe the high-access strategies and provide examples that demonstrate how teachers can incorporate the strategies into their lessons to effectively accommodate the needs of diverse learners.

\section{Choral, or Group, Responding}

1. Ask a question and tell students, "Think-don't blurt out."

2. Provide thinking time.

3. Provide a simple oral or visual cue that will signal all students to respond together.

Choral, or group, responding is an age-old strategy that works very well when the answers are short and the same (Archer, Gleason, \& Issacson, 1995; Carnine, Silbert, \& Kameenui, 1997). It provides a safe environment for practicing new skills while keeping engagement and attention focused for all students. The teacher teaches the students how to think first and then, upon a signal such as lowering both hands, to respond as a group.

Consider, for example, a first-grade teacher reviewing the sight word "was." He or she could use choral responding to ensure that all students look at the word, think about how to say it, and then say it together. The teacher would point at the word on the overhead projector and ask everyone to look at it and think about what it says. After a minute or two, the teacher would give a signal for the class to respond as a group. Individual mistakes in the group responses would cue the teacher to review the sight word in more detail before going on with the lesson.

\section{Thumbs Up When You Know}

1. Ask a question and tell students, "Think—don't blurt out, and put your thumb up when you know."

2. Provide thinking time.

3. Check to see that most students have their thumbs up.

4. Either call on students randomly or cue students to respond chorally as a group (if the answer is short and the same).

Thumbs Up allows students to demonstrate that they know an answer without blurting it out, which, as noted earlier, deprives other students of the critical time they may need to cognitively process the question and form an answer. Secondary teachers often use a modification of the Thumbs Up approach by asking students to make eye contact with them when they are ready to answer. Both approaches provide all students with valuable thinking time, prevent the blurting out of answers, and give the teacher a quick and immediate assessment of student knowledge and ability to respond successfully. In addition, they avoid the pitfalls of calling on students who are not prepared or do not feel comfortable responding.

A fifth-grade teacher might, for example, ask students to reflect on the critical attributes of cold-blooded animals just reviewed in a video on the subject and to put their thumbs up when they can identify at least one. The teacher would then randomly call on individual students or ask the students to whisper the answer to their partners. Thus, all students would be actively engaged in reflecting on key aspects of the video and would have a nonthreatening opportunity to participate in the class dialogue.

\section{Classroom Whip Around}

1. Pose an open-ended question. Answers must be a word or a phrase, 10-word limit.

2. Provide thinking time, and model a response if needed (partner responses can be used instead to better ensure that all students have something to contribute).

3. Start anywhere in the class and "whip around the room" having students quickly share their answers. Allow no discussion or comments.

4. Students have the right to pass.

The Classroom Whip Around is a fun, engaging strategy that provides students with the opportunity to practice summarization and oral recitation in a safe classroom environment. The whip is particularly useful for encouraging students to identify key big ideas, themes, and summative information at the end of a lesson or activity. Teachers can modify the whip by having students write their answer on a sheet of paper and simply stand to show the class their written response as the "wave" circulates around the classroom.

The following scenario illustrates the Classroom Whip Around strategy. At the end of an eighth-grade geography lesson, students are asked to reflect on one important attribute of the region they have been studying. The teacher provides thinking time, inviting the students to put their thumbs up or make eye contact when they are ready to respond. Then he or she "whips around" the classroom giving each student a brief chance to share one attribute. Further discussion takes place after all students have the chance to respond.

\section{Partner Strategies}

Perhaps the most flexible set of HAI strategies involves various forms of structured partner responding. In all of these partner strategies, the teacher matches each student to an 
appropriate partner (i.e., high-performing students with middle-performing, middle-performing with lower-performing students) and provides the partners with specific roles for the activity. Partner responding works well across the educational spectrum, from kindergarten through graduate school classrooms.

\section{Think-(Write)-Pair-Share}

1. Pose an open-ended question (no single answer).

2. Provide time for students to think of answers (it can be useful to have older students write responses in a notebook/double-entry journal).

3. Have students form pairs. Designate students in each pair as a "one" or a "two." Direct "ones" to share answers with their partners for a minute or two, then reverse the process.

4. Randomly call on individuals to share with the class.

Think-Pair-Share (Kagan, 1992) is a versatile highaccess strategy. It is particularly useful for open-ended questions that have many possible answers, such as used in brainstorming. Success with this and other partner strategies revolves around carefully structuring each detail involved in the activity. Care should be taken, for example, to structure the time frame (start short, 1-2 minutes), topic, role, and social expectations.

This example illustrates the Think-(Write)-Pair-Share strategy. A high school English teacher asks students to reflect on a character in a novel they are reading and then to individually write a list of as many attributes as they can that are distinctive about the character. After a few minutes, the teacher directs the students to work in pairs. The teacher instructs the "ones" to share what they have written about the character while the "twos" practice good listening skills. At the end of 2 minutes, he instructs the "twos" to share what they found distinctive about the character. He encourages the students to add useful items learned from their partner to their own master list. The teacher carefully monitors student responses by listening to selected pairs as they converse. This provides him with an opportunity to informally assess how well students understand the information and if more examples or practice would be helpful. After Think-(Write)Pair-Share, the teacher asks the students to compose, as a homework assignment, a brief essay comparing and contrasting the key attributes of this character with the protagonist of a novel they read earlier in the semester.

\section{Tell-Help-Check}

1. Assign partners. Designate students in each pair as a "one" or a "two."

2. Pose a closed-ended question (one right answer).

3. Give thinking time.
4. Have one partner in each pair tell the other all he or she can recall about the topic/subject/question (encourage students to make educated guesses-tell them to "give it a go").

5. Explain that the other partner helps by adding anything the "teller" left out, by correcting, by elaborating, and so on.

6. Explain that both partners will then check in the book, notes, overhead, etc., and validate, correct, or elaborate on their answers.

Research (Rosenshine, 1987) and common sense suggest that review of critical information is vital for all students, especially those most at risk for school failure. Evidence also suggests that teachers and higher-achieving students actually do most of the reviewing that takes place in the typical classroom (Schumm \& Vaughn, 1995; Thomas \& Rohwer, 1987). In fact, the students who most need to generate a response or practice their emerging English are the very students least likely to be actively engaged in classroom review activities. Tell-Help-Check (Archer, 1999) offers teachers a robust strategy for ensuring that all students are actively involved in systematic review of critical information, regardless of their prior knowledge or proficiency in English. This strategy works well when reviewing factual information that has discrete right and wrong answers.

As an example, a high school science teacher could ask her students to describe the key phases of the convection cycle they have been studying. "Ones" would tell "twos" all they could, and "twos" would help by adding, correcting, or elaborating on "ones" responses. Finally, the partners together would check the responses by reviewing a graphic in their text that summarizes the information. Whole class discussion could then be conducted to provide additional information or examples the teacher felt were necessary. Tell-Help-Check is a textbook example of a high-access instructional strategy that dramatically increases the active participation of all learners, thus ensuring that the students, not the teacher, are actually doing the cognitive work of reviewing.

\section{Do-Check-Teach}

1. Assign students to partners with adjacent achievement levels. ${ }^{1}$

2. Pass out the problems/worksheet and the answer key.

3. Instruct partners to individually (independently) answer the first question without looking at the answer key.

\footnotetext{
${ }^{1}$ A quick format for determining adjacent levels in reading is to rank order your classroom and then place the top student with the middle student and so forth. For example, in a class of 30, Student 1 would partner with Student 16, Student 2 with Student 17, and so on.
} 
4. Have partners compare answers and compare their answers to the answer key.

5. If either partner missed the question, the other student should teach him or her how to work it out correctly.

6. If both partners missed the problem, they should ask another pair or you for assistance.

Do-Check-Teach is a simple partner strategy that is ideal for enhancing independent seat work in math. Similar in nature to Kagan's (1992) Pairs Check, Do-Check-Teach helps students focus on the purpose of practice by providing them with the answers for checking their work. Students are reminded that the reason for doing the worksheet is to become fluent with the process or strategy recently covered in class, not simply to arrive at the right answers. If both partners struggle, they can ask a nearby pair for assistance or summon the teacher. Use of Do-Check-Teach also gives teachers time to circulate and provide individual pairs with additional instruction, modeling, and other personalized assistance.

A primary-grade teacher might use Do-Check-Teach with her students to practice recently taught math skills. By having the time to circulate, the teacher would be able to differentiate her teaching and provide individual pairs with the exact practice they need, thereby avoiding a "one-size-fitsall" approach. Topics could range from single column addition to addition with regrouping to subtraction with borrowing. The students would also benefit from the immediate feedback by their assigned peers.

\section{Classwide Peer Tutoring/Peer-Assisted Learning}

1. Partner students via adjacent achievement levels.

2. Structure partner activity (e.g., for reading fluency, "ones" could read for 5 minutes followed by "twos" rereading the same passage for 5 minutes; continue for 20 minutes).

3. Partners earn points for on-task behavior.

4. Tutors provide partners with error correction as needed.

5. Team points are totaled weekly.

Classwide Peer Tutoring (CWPT) offers a wide range of effective high-access instructional opportunities. An extensive research base documents its effectiveness in heterogeneous elementary and secondary classrooms for developing basic skills in reading, math, and spelling (Greenwood \& Delquadri, 1995). Peer-Assisted Learning Strategies (PALS), elaborations of CWPT (Fuchs, Fuchs, Mathes, \& Simmons, 1997), are particularly helpful for teachers in grades 2-8 facing the challenge of diverse reading levels among their students. To implement PALS Reading, for example, the teacher structures partner reading wherein students take turns engaging in the following sequence of activities to promote reading fluency and comprehension:

\section{Peer-Assisted Learning Strategies Reading}

1. Partner 1 predicts what will happen next in a reading passage at the partners' instructional level.

2. Partner 1 then reads the section of text orally and monitors his or her prediction.

3. Partner 1 summarizes the text and says who/what the section was about - that is, the topic.

4. Partner 1 tells the most important thing about the topic, adding pertinent details.

5. Partner 1 paraphrases in 10 words or fewer the "gist" of the section.

6. Partner 2 makes a new prediction about the same section and repeats the sequence.

7. With PALS Reading, the partners take turns reading and asking each other the comprehension questions while the teacher monitors individual pairs.

Like CWPT, Peer-Assisted Learning Strategies allow teachers to differentiate instruction by having students read in texts at their instructional level while the whole class is practicing the same reading strategy (e.g., prediction, summarization). Mathes, Howard, Allen, and Fuchs (1998) recently demonstrated that a modification of PALS is equally effective for assisting first-grade readers in the acquisition of beginning reading skills.

The following example shows how PALS can be used: A fourth-grade teacher might set up PALS reading practice for 40 minutes a day. He would partner students with adjacent reading levels and find appropriate texts to match their average instructional level, ranging from second- to seventhgrade texts. The partners would take turns reading and practicing comprehension strategies using the PALS guidelines. The teacher would circulate to listen to students as they read orally and practiced their comprehension strategies.

\section{Cloze Reading With Choral Responding}

1. Read material from the text aloud to the class.

2. Have students follow along in their books.

3. Leave out selected words every sentence or so.

4. Have students read the left-out words chorally.

A powerful alternative to round-robin reading is cloze reading with choral responding. This strategy gives all students access to the information in the text, focuses their attention, and allows for diverse reading levels among students. The teacher reads aloud while the students follow along in their books (primary students can use their fingers as well). The teacher leaves out selected words that most 
students will be able to read, and the whole class reads those words together chorally. Care should be taken to keep the pace lively to encourage all students to read the words that are left out.

Consider this scenario: A seventh-grade history teacher realizes that one half of her class cannot independently read the text. Moreover, when she reads aloud, many students are inattentive. By leaving out a word every sentence or two and prompting students to respond as a group, attentiveness increases. She makes sure that the majority of the words she leaves out are words that most of the students can read independently. With this strategy, less confident readers as well as English language learners have a safe environment in which to practice their emerging language skills without holding the class back from exploring content area concepts.

\section{Random Questioning With $3 \times 5$ Name Cards}

1. Write all the students' names on $3 \times 5$ cards.

2. Pose a question and give thinking time.

3. Use Thumbs Up or partners to ensure that all students are prepared to respond productively.

4. Randomly select a student to give the answer by picking the next card in the pile of $3 \times 5$ cards.

Students often enjoy game-like formats, which enliven class discussion. The use of $3 \times 5$ cards adds an enjoyable element to the discussion process while making students accountable for their learning. Step 3 is the key to success when using this strategy. It ensures that all students have access to the information prior to the teacher having a student answer the question.

A middle school teacher might conduct the review of study questions at the end of a history chapter by combining Think-Pair-Share and $3 \times 5$ cards to create a lively discussion. If extra pizzazz is desired, the teacher could place half of the class on one team and half on another and keep a running score of correct responses for each team.

\section{Give One-Get One}

1. Pose a question that requires a list of answers. Have students brainstorm the answers individually and write them down in a list.

2. Have students draw a line after the final idea they noted.

3. At your signal, invite students to move around the classroom to get at least one additional idea to add to their list and to give at least one idea from their list to a classmate.

4. Have students return to their seats, review their new lists, and discuss the items with a partner or the whole class.
Brainstorming is an important classroom activity with endless permutations. Give One-Get One provides an interesting brainstorming variation by giving students a chance to get up and move around the classroom in a structured manner while at the same time holding them accountable for a productive outcome.

For example, a sixth-grade teacher could ask students to list all of the possible reasons people immigrated to the United States in the 1840s. Then, using Give One-Get One, she could give students 4 minutes to add reasons to their lists (below the line on their papers) as they circulate around the classroom. After 4 minutes, the teacher would give a "wrap it up" signal, and the students would return to their seats to review their new lists. Using Think-PairShare, the teacher might then direct the students to select the three most compelling reasons from their newly expanded lists and discuss with a partner why they chose them. Whole class discussion using $3 \times 5$ cards could follow with the teacher helping students to grapple with the key ideas behind immigration to the United States in the mid-19th century.

\section{Heads Together}

1. Place students in heterogeneous teams of three or four (combine two pairs if using partners regularly).

2. Have students number off (e.g., 1, 2, 3, 4).

3. Explain that you will pose a question and set a time limit for the groups to discuss the answer.

4. Inform the teams that you will randomly select one number and the person in each team with that number will be accountable for sharing the group's answer.

5. Pose a question that requires conversation and elaboration. Set a time limit.

6. Have the students put their heads together to find the answer.

7. Randomly select one number. Have the "lucky" students share answers with the class.

Classroom discussions are notorious for lack of equitable student participation. At a recent conference session on curricular adaptations for secondary students, one teacher quipped, "The same kids participate in high school who did in third grade!" Unfortunately, the research data support this observation. Heads Together offers teachers a simple, yet elegant, alternative to traditional classroom discussions driven by hand raising. It provides all students with access to critical information while making each student responsible for responding to the question at hand. Heads Together increases performance in content area discussions and content tests for all levels of students in diverse classroom settings (Maheady, Mallette, Harper, \& Sacca, 1988). Our 
observations suggest that teachers may want to assign additional roles of "checker" and "discussion facilitator" to provide even more structure for the discussion. The checker simply checks to make sure that all group members can answer appropriately if called upon; the discussion facilitator's job is to ensure that all group members participate and share information.

Here's an example of classroom use of the Heads Together strategy. A third-grade teacher places students into heterogeneous teams of four and asks them to think about and discuss four questions they would like to ask the author of the novel they have just finished. After 7 minutes of intense dialogue, the teacher brings the class back together, using the predetermined signal of turning the lights off and on once to get student attention. After the signal, the students stop talking and watch intently as the teacher spins a spinner on his desk to see who the "lucky winners" will be. The spinner lands on 4. All "fours" stand up, and the teacher randomly calls on each to share one idea. The whole class claps for each student after he or she shares an idea. After each student shares, he or she takes a seat. At the conclusion of the sharing, the teacher adds additional comments to tie the ideas together. For homework, students compose individual letters to the author using one or two of the questions generated in their Heads Together team.

\section{Ambassadors}

1. Follow the same procedures as for Heads Together.

2. After choosing the lucky number, have each of the selected students go to the group closest, clockwise, to him or her. Explain that each group is a foreign country and that each selected student is an "ambassador."

3. Have the ambassadors share their groups' answers with the "foreign country" and ask for one different answer that they can take back "home" to share.

4. Have the ambassadors return home to share what they have learned with their team members.

Ambassadors can be a particularly effective strategy for increasing access to learning in diverse classrooms. It allows students to practice oral recitation in the relatively nonthreatening context of a small group, instead of before the entire class. Like Heads Together, Ambassadors allows students with less prior knowledge to benefit from the team's combined knowledge, while at the same time holds individuals accountable for learning, because no one knows who will be selected until the number is chosen. If the topic is particularly open ended and complex, teachers may want to have the ambassadors make rotations to two or more different groups. Doing so not only expands the knowledge base of each group but provides each individual ambassador with repeated practice presenting his or her information. This type of authentic practice is exactly what English language learners, low achievers, and other diverse learners need to master critical information in a safe learning community.

The following scenario shows a classroom situation that is ideal for Ambassadors. A ninth-grade social studies teacher is working with her students to understand why Sumaria was an important civilization in the ancient world. She assigns each team of four the task of determining the four major reasons for why Sumaria was an important civilization. At the end of a Heads Together-type discussion, she randomly selects "threes" to be the appointed ambassadors. All "threes" stand and "fly" to the country to their right with a "visa" that expires in 5 minutes. They must share their group's four reasons and rationales and then must come back "home" with at least one new reason learned from the "foreign country." At the end of 5 minutes the teacher gives the signal for the ambassadors to return "home" and share what they learned. A classwide discussion follows, bringing to light interesting answers from all countries. For homework, each student writes a short paper describing why ancient Sumaria was an important civilization.

\section{Reciprocal Teaching}

1. Demonstrate and model the four strategies of reciprocal teaching: predictions (cover what they are, why they are useful, and what makes a good one); questions (cover how to phrase them and why they are so helpful in reading); clarifications (cover what they are, how to phrase them, and why they are useful); and summaries (cover what they are, examples of paraphrasing, and how summaries help text understanding).

2. Read aloud, or have students silently read (if students have the decoding skills), a section of text (a paragraph or page).

3. Then lead students through a dialogue using the relevant reciprocal teaching strategies, taking care to model the thinking that would be used when applying each strategy.

4. Provide ongoing practice by shifting control for leading discussion to the students as longer passages of text are being read.

Palinscar and Brown (1984) documented the effectiveness of reciprocal teaching for developing reading comprehension with diverse students. The demonstrations and modeling show students exactly how to perform a task so that they can better comprehend narrative and factual text. The key to success with reciprocal teaching, as well as other reading comprehension strategies, is to overtly model the thinking one might use when applying the strategy (Pressley, El-Dinary, et al., 1992). 
For example, a sixth-grade teacher modeling prediction when prereading a science textbook might say, "Let's see. We know these plants capture insects to eat, but the author hasn't told us anything about how the plants actually attract and seize them. I predict in the next section the author will tell us ..." As the class continued to read the selection, the teacher would stop to model each of the four reciprocal teaching strategies and would prompt the students to practice using the strategies with their partners. Over the next 4-6 weeks, the students would take more and more control of the modeling and of directing the reciprocal teaching process in content area texts.

\section{LOW-AND HIGH-ACCESS INSTRUCTION CONTRASTED}

The purpose of HAI extends beyond incorporating a few calculated instructional tricks into classroom instruction. The challenge rests in the responsibility of the teacher to create a classroom that honors active thinking and discussion while at the same time advocates for and promotes student construction of meaning either individually or as a group. In high-access classrooms, teachers are accountable for ensuring that all students are active participants in each instructional activity. These teachers understand that "learning is not a spectator sport" (Archer, 1999). The differences between high-access and low-access instruction are summarized in Table 1.

\section{SUMMARY}

Low-access classroom activities go on in almost every classroom in America that unintentionally exclude many diverse students from having meaningful access to learning. This typical, or generic, instruction is a product of years of creating schools as assembly lines, with the underlying assumption that diversity was a problem to either ignore or eliminate. Yet, American schools are continuing to become more diverse in terms of achievement level, educational background, home language, and ethnicity. Traditional "teach to the middle" approaches to instruction and unintentional tracking into high, middle, and low groups simply do not work. Mounting research (Pressley, Harris, \& Marks, 1992; Pressley, Hogan, Whareon-McDonald, \& Mistretta, 1996) suggests that when teachers systematically apply high-access strategies across the curriculum, learning gains accrue for all levels of students. In essence, high-access instruction offers educators an opportunity to capitalize on the diversity in their classrooms without compromising the integrity of classroom expectations and while meeting state and district standards.

We believe that teachers need specific research-validated instructional tools, such as those described in this article, that will empower them to effectively respond to the challenges posed by increased academic diversity, including serving students identified as learning disabled. Teachers and other professionals are encouraged to use these and other high-access practices, to dialogue with others who are

\section{TABLE 1}

\section{Contrast Between Low- and High-Access Strategies}

\section{Low-Access Strategies}

Engage students one at a time

Offer little or no thinking time

Assume adequate prior knowledge and skills

Focus on coverage of content and skills

Create high levels of threat/discomfort for diverse learners

Do not differentiate for skill levels ("one size fits all")
High-Access Strategies

Engage all students simultaneously

Prioritize thinking time for all

Assume diverse prior knowledge and skills

Focus on learning of skills and content

Create low levels of threat; diverse learners are "set up for success"

Differentiate instruction for different skill levels and learning needs

Provide careful structuring of student interaction (teacher acts as "learning choreographer") 


\section{SPECIAL EDUCATION POLICY AND PRACTICE}

\section{Accountability, Instruction, and Social Challenges}

Thomas M. Skrtic

Karen R. Harris

James G. Shriner

This is an excellent book that addresses the policy shift in special education from procedural compliance to standards-based accountability and the changing conditions of practice under reform. It covers the major problems of implementing reform and presents several practices and models to improve the conditions of special education practice.

The authors support a collaborative environment for service delivery and inclusive work atmospheres with research-based instructional practices. The book gives prevention and intervention strategies including specific reading, writing, and mathematics instructional techniques. Other topics include transition, selfdetermination, school violence, health needs, and literacy instruction for Latino students.

The focus in the last part of the book is oriented to human needs and opportunities that will shape special education practice in the future including individual and environmental conditions. These include welfare of children working across social contexts and providing a planning framework for achieving integrated services.

\section{SPECIAL FEATURES}

- Clear explanation of policy shifts from procedural compliance with federal and state law to academic performance of students with disabilities

- Recommends strategies for improving academic learning for students with disabilities

- Considers human needs and environmental conditions that contribute to educational achievement of children

- Provides an action-oriented planning framework for achieving integrated services 
attempting to implement them, and to work together to transform the learning landscape from providing generic opportunity to truly providing meaningful access for all.

\section{REFERENCES}

Archer, A. (1999). Skills for school success. Workshop presentation. San Jose State University Summer Educators Workshop (June), San Jose, CA.

Archer, A., Gleason, M., \& Issacson, S. (1995). Effective instructional delivery. In P. T. Celgelka \& W. H. Berdine (Eds.), Effective instruction for students with learning difficulties (pp. 161-194). Boston: Allyn \& Bacon.

Carnine, D. W., Silbert, J., \& Kameenui, E. J. (1997). Direct instruction reading. Englewood Cliffs, NJ: Prentice-Hall.

Cohen, E. (1994). Designing group work: Strategies for the heterogeneous classroom. New York: Teachers College Press.

Denti, L. (1994). Walling students with disabilities out of the mainsteam: Revealing the illusions of inclusion. International Journal of Group Tensions, 24(1), 69-78.

Deshler, D. D., \& Schumacker, J. B. (1986). Learning strategies: An instructional alternative for low-achieving adolescents. Exceptional Children, 52, 583-589.

Ensminger, G. (1991). Defragmenting fragmented learners. Hands On: A Journal for Teachers, 39, 44-48.

Fuchs, D., Fuchs, L., Mathes, P., \& Simmons, D. C. (1997). Peer assisted learning strategies: Making classrooms more responsive to diversity. American Educational Research Journal, 34(1), 174-206.

Goodlad, J. I. (1984). A place called school: Prospects for the future. New York: McGraw-Hill.

Greenwood, C. R., \& Delquadri, J. (1995). Classwide peer tutoring and the prevention of school failure. Preventing School Failure, 39(4), 21-25.

Kagan, S. (1992). Cooperative learning resources for teachers. San Juan Capistrano, CA: Kagan Cooperative Learning.

Kameenui, E. J., \& Carnine, D. W. (Eds.). (1998). Effective teaching strategies that accommodate diverse learners. Columbus, $\mathrm{OH}$ : Merrill.

Katz, M., \& Denti, L. (1996). The road to nowhere begins with where we are: Rethinking the future of American education. Interchange, 27(3-4), 261-277.

Keogh, B. K. (1990). Narrowing the gap between policy and practice. Exceptional Children, 57, 186-190.

Knight, J. (1998). Do schools have learning disabilities? Focus on Exceptional Children, 30(9), 1-14.

Maheady, L., Mallette, B., Harper, G., \& Sacca, M. K. (1988). Heads together: A peer mediated option for improving the academic achievement of heterogeneous learning groups. Remedial and Special Education, 12(2), 25-33.

Mathes, P. G., Howard, J. K., Allen, S. H., \& Fuchs, D. (1998). Peer assisted learning strategies for first grade readers: Responding to the needs of diverse learners. Reading Research Quarterly, 33, 62-93.

McIntosh, R., Vaughn, S., Schumm, J. S., Haager, D., \& Lee, O. (1993). Observations of students with learning disabilities in general education classrooms. Exceptional Children, 60, 249-261.
Palincsar, A. S., \& Brown, A. L. (1984). Reciprocal teaching of comprehension fostering and comprehension monitoring activities. Cognition and Instruction, 1(2), 117-175.

Palincsar, A., \& Klenk, L. (1992). Fostering literacy learning in supportive contexts. Journal of Learning Disabilities, 25(4), 211-215, 229.

Pressley, M., El-Dinary, P. B., Gaskins, I., Schudder, T., Bergman, J. L., \& Brown, R. (1992). Beyond direct explanation: Transactional instruction of reading comprehension strategies. Elementary School Journal, 92, 511-554.

Pressley, M., Harris, K. R., \& Marks, M. B. (1992). But good strategy instructors are constructivists!! Educational Psychology Review, 4, $1-32$.

Pressley, M., Hogan, K., Wharton-McDonald, R., \& Mistretta, J. (1996). The challenges of instructional scaffolding: The challenges of instruction that supports student thinking. LD Research and Practice, 11(3), $138-146$

Rosenshine, B. (1987). Explicit teaching. In D. Berliner \& B. Rosenshine (Eds.), Talks to teachers (pp. 75-92). New York: Random House.

Schumm, J. S., \& Vaughn, S. (1995). Getting ready for inclusion: Is the stage set? LD Research and Practice, 10(3), 169-179.

Schumm, J. S., Vaughn, S., Gordon, J., \& Rothlein, L. (1994). General education teachers' beliefs, skills, and practices in planning for mainstreamed students with learning disabilities. Teacher Education and Special Education, 17(1), 22-37.

Simmons, D. C., \& Kameenui, E. J. (1996). A focus on curriculum design: When children fail. Focus on Exceptional Children, 28(7), 1-16.

Slavin, R. E. (1984). Team assisted individualization: Cooperative learning and individualized instruction in the mainstreamed classroom. Remedial and Special Education, 5(6), 33-42.

Stainback, W., \& Stainback, S. (1984). A rationale for the merger of regular and special education. Exceptional Children, 51(2), 102-111.

Steinberg, Z. (1991). Pandora's children. Beyond Behavior, 2(3), 5-14.

Thomas, J. W., \& Rohwer, W. D., Jr. (1987). Grade-level and course-specific differences in academic studying: Summary. Contemporary Educational Psychology, 12, 381-385.

Vaughn, S., Schumm, J. S., Jallad, B., Slusher, J., \& Saumell, L. (1996). Teachers' views of inclusion. LD Research and Practice, 11(2), 96-106.

Vaughn, S., \& Schumm, J. S. (1995). Responsible inclusion for students with learning disabilities. Journal of Learning Disabilities, 28 , 264-270.

Wang, M. C., Reynolds, M. C., \& Walberg, H. J. (1986). Rethinking special education. Educational Leadership, 44, 26-31.

Zigmond, N., \& Baker, J. M. (1995). Concluding comments: Current and future practices in inclusive schooling. Journal of Special Education, $29,245-250$.

Zigmond, N., \& Thorton, H. (1985). Follow-up of postsecondary-age learning disabled graduates and drop-outs. Learning Disabilities Research (1), 50-55.

Vygotsky, L. S. (1978). Mind and society. Cambridge, MA: Harvard University Press. 